\title{
Effects of Visually Enhanced Input, Input Processing and Pushed Output on Grammar Teaching
}

\author{
NeSRÍN ORUÇ ERTÜRK \\ İzmir University of Economics, Turkey
}

Received: 29 April 2011 / Accepted: 14 December 2012

ISSN: $1697-7467$

\begin{abstract}
Empirical evidence from studies investigating the output hypothesis lends at least some support to the notion that output might have beneficial effects on linguistic development in addition to- not in opposition to- the crucial role of input. This study attempts to address this issue by exploring the consequent effects of the input-output relationship and whether output, input processing or visual input enhancement can promote both the learning and retention of English. In a quasi-experimental design with three experimental and one control group, participants were presented the same linguistic item and data was collected with pre-post tests. Results reveal gains for the pushed output group; however, visually enhanced input fails to take the attention of learners to the linguistic item in the input.
\end{abstract}

Keywords: focus on form, visually enhanced input, pushed output, processing instruction.

Los efectos del input visualmente mejorado, el procesamiento del input y output dirigido en la enseñanza de la gramática

RESUMEN: Distintos estudios ofrecen evidencia de que la hipótesis del output apoya la idea de que el output puede tener efectos beneficiosos en el desarrollo lingüístico además del papel crucial que desempeña el input. Este estudio trata este tema explorando los efectos de la relación input-output y si el output, el procesamiento del input o el mejor aprovechamiento del input visual puede mejorar el aprendizaje y retención de la lengua inglesa. Los participantes en el experimento, consistente en tres grupos experimentales y uno de control, tuvieron los mismos items y se recogieron datos mediante tests previos y posteriores. Los resultados revelan mejores resultados para el grupo de output forzado; sin embargo, el input resaltado visualmente no atrae la atención de los aprendices.

Palabras clave: atención a la forma, input resaltado visualmente, output forzado, instrucción de procesamiento.

\section{INTRODUCTION}

While the role of instruction is being discussed in the literature, it is widely accepted that input-based instruction plays a crucial role in the acquisition of second languages 
(Brown, 1985; Ellis, 1985). Put simply, learners of a second/foreign language will not learn the language unless exposed to it both orally and visually i.e. in writing. The input approach takes as its starting point the assumption that language learning is stimulated by communicative pressure and examines the relationship between communication and acquisition and the mechanisms (e.g., noticing, attention) that mediate between them (Gass, 2003).

Another component that has been argued to be essential in the acquisition of second languages is output. It is accepted that output-based instruction is essential in the process of learning a second/foreign language (Swain, 1985; 1993; 1995; 1998). Based on her observations of the lack of target like output at children after several years of immersion programs in Canada, Swain discusses the need for producing the Target Language to serve as the trigger that forces the learner to pay attention to the means of expression needed in order to successfully convey his or her own intended meaning(Swain, 1985: 249).

Following the idea that both input- and output-based instruction can be effective for second language acquisition (SLA), many studies have attempted comparisons under a variety of research designs (Ellis \& He, 1999; Mackey, 1999; Pica \& Doughty, 1985; Swain, 1985, 1993, 1995, 2000). Few studies have specifically addressed whether output-based instruction can be as effective as input-based instruction (Izumi, 2002). However, there are still unanswered questions in the literature in terms of the degree of effects of visually enhanced input, processing instruction and pushed output on the acquisition of English as a second language. Further, as Gass (2004) has pointed out, today's research world is dealing with theories depending on input-output relationships, and these kinds of studies are becoming increasingly prominent.

Therefore, this study aims at investigating the possible effects of processing instruction, visually enhanced input and pushed output in grammar instruction, namely focus on form in the learning of Type 3 Conditional sentences of English as a second language by Turkish learners. It further aims at investigating the degree to which interlanguage development retains over time (as determined by the results of the delayed post-tests).

\section{THEORETICAL FRAMEWORK}

The term focus on form, first used by Long (1991), has been derived from the communicative language teaching approach as a type of instruction in which the primary focus is on meaning and communication, with the learners' attention being drawn to the linguistic items in the input. It differs from the more traditional focus on forms, where, as with all other teaching methods, the linguistic forms themselves are the basis of material design.

\subsection{Input and Second Language Acquisition}

The essential nature of the role of input in the learning of L2 is emphasized by Gass \& Torres (2005), who describe it as the sine qua nonof education. No theories or approaches to SLA underscore the importance of input, although theories differ as to its significance. For Cook (2001), the purpose of language teaching in a sense is to provide optimal samples of language or the learner to profit from the best input to the process of language learning. Everything the teacher does provide the learner with opportunities for encountering the language. 
VanPatten (2003: a) defines input as the language that a learner is exposed to that has some kind of communicative intent. Communicative intent here refers to the message in the language that the learner is supposed to attend to and/or respond to. The job of the learner is to comprehend the message.

\subsection{Input Processing}

A crucial role in understanding the role of input relates to processing. VanPatten (2003) is concerned with what he refers to as input processing, which deals with presentation and timing of input. In cognitive psychology it is stated that attention is selective and limited (Schmidt, 2001). Given this limited attentional capacity, only a limited amount of incoming data may be attended to at a given time. Thus, VanPatten (1994) proposed that form and meaning may compete for attentional resources. Because the communicative goal of the learner is to understand the content of the message rather than how it is encoded, the learner will process input for meaning before form.

Input processing consists of two sub-processes: making form-meaning connections and parsing. Making form-meaning connections, means being able to get data from the input as that $s$ at the end of a verb means someone else or third person singular. Parsing refers to mapping syntactic structure onto utterance, for example knowing which noun is the subject, and which is the object. When the input is adjusted for level, learners have less of a comprehension burden and thus the likelihood of their attending to form increases.

\subsection{Processing Instruction}

VanPatten (2002) defines processing instruction (PI) as a type of grammar instruction or focus on form derived from the insights of input processing. For Doughty (2001) processing instruction is a pedagogical intervention designed to influence L2 learners' processing of input such that it more readily and efficiently becomes intake. In particular, processing instruction aims to make the most difficult and therefore least natural to pay attetion to aspects of the input salient to L2 learners. The most salient characteristic of PI is that it uses a particular type of input to push learners away from nonoptimal processing strategies. Therefore, VanPatten (2002) claims that since the point of PI is to assist the learner in making form-meaning connections during IP, it is more appropriate to view it as a type of focus on form. A secondary salient characteristic of PI is that learners are never asked to produce the target form during the instructional phase, but instead, process sentences and interpret them correctly while attending to form.

\subsection{Input Enhancement}

In our discussion of the importance of input in SLA, it was stated that research considers input as being a necessary but insufficient condition for SLA (Larsen-Freeman and Long, 1991). It is believed that not all of the input that learners are exposed to is utilized as intake for learning. Therefore recent research in SLA has examined the role of attention in mediating input and learning. A general finding of such research indicates that attention is necessary for learning to take place. As stated by Schmidt $(1995,2001)$ the more atten- 
tion given, the greater the learning. In his Noticing Hypothesis, Schmidt (1990) claims that intake is that part of the input that the learner notices. He went further to argue that SLA is largely driven by what learners pay attention to and notice in target language input.

The position that learning without attention is not possible is also defended by Carr and Curran (1994: 207), who stated that:

There is little compelling evidence that requires anyone to believe in a strong form of 'unconscious abstraction'- the full construction of very abstract rule systems completely outside of awareness- and that there is compelling evidence that focused attention is needed for structural learning even if what is being learned does not reach conscious levels of processing. It is argued that unattended stimuli persist in immediate short-term memory for only a few seconds at best and attention is the necessary and sufficient condition for long-term memory storage to occur.

Taking the central role of attention in learning as a starting point of investigation, recent SLA research has begun to explore whether and how the learners' attentional processes may be influenced for the sake of their greater interlanguage development. Such consideration is indeed at the core of influential pedagogic proposals known as consciousness-raising (Smith, 1993) and focus on form. Specific pedagogical approaches to draw the learners' attention to form -namely; input enhancement and learners' output- have received considerable attention in recent SLA research.

Smith (1993) described input enhancement as the process of drawing learners' attention to specific features of language through highlightining. He pointed out that input enhancement can be internally and externally driven. Externally driven enhancement occurs when a teacher, through a variety of means, draws attention to a particular area of language (e.g. through a structured task or an overt explanation). Internally driven enhancement comes about through learners' own devices when they attend to something themselves (e.g. due to salience or frequency).

Input and especially enhanced input, essential in determining the other factors which contribute to the processes involved in language learning, need to be considered with a multiplicity of factors in order to determine learner development. Among these, output has a crucial role.

\subsection{Output and Second Language Acquisition}

Current SLA research, however, goes beyond general interest in the need for comprehensible input, considered necessary, but insufficient in itself, mainly because not all of the input is utilized as intake for learning (Larsen-Freeman and Long, 1991). Gass \& Selinker (2001) state that input alone is not sufficient for acquisition because when one hears language, one can often interpret the meaning without the use of syntax. Hearing the words dog, bit, girl one can understand that the meaning is The dog bit the girl. So, little knowledge is needed to interpret the meaning. Output, on the other hand, has not been seen as a way of creating knowledge, but as a way of practicing already existing knowledge. 
On this topic, Swain (1985) gives the example of French Immersion Programs in Canada, which aim at both the achievement of general and academic L2 through an integration of language and content teaching. These programs achieved great success in many areas of development; however, problems in some aspects of the target language grammar have been found. Despite being exposed to a rich source of comprehensible input over a period of eight years, Swain $(1985,1993,2000)$ noted that their interlanguage performance was still off-target; that is they were clearly identifiable as nonnative speakers or writers. In particular, Swain found that the expressive performance of these students of French was far weaker than that of same-aged native speaker. For example, they evidenced less knowledge and control of complex grammar, less precision in overall use of vocabulary and morphosyntax, and lower accuracy in pronunciation. Swain $(1985,2000)$ argues that one of the important reasons for problems in grammar is too little production, which prevents them from going beyond a functional level of L2 proficiency. She states that the interlanguage performance of these students was still off-target because of the lack of two opportunities: First, the students are simply not given especially in later grades- adequate opportunities to use the target language in the classroom context. Second, they are not being pushed in their output.

Observation such as these have led Swain to conclude that comprehensible input, while invaluable to the acquisition process, is not sufficient for these students to fully develop their L2 proficiency. What these students need, Swain argued, is not only comprehensible input, but comprehensible output to improve both fluency and accuracy in their interlanguage. As Swain (1995: 128) states:

Output may stimulate learners to move from the semantic, open-ended nondeterministic, strategic processing prevalent in comprehension to the complete grammatical processing needed for accurate production. Output, thus, would seem to have a potentially significant role in the development of syntax and morphology.

The construct of comprehensible output posits that when learners experience communication difficulties, they will be pushed into making their output more precise, coherent and appropriate, and this process is said to contribute to language learning (Izumi, 2003). Similarly Shehadeh (2002) describes this phenomena as push(ing) learners to make their output more precise, coherent thus developing SLA.

\subsection{Pushed Output}

Following more closely Swain's notion of Pushed Output, experimental studies that seek to manipulate output as a variable might suggest that learners can divide their attention between many different features of language. An example study along these lines is Izumi (2002), where learners were exposed to input only or input/output cycles in learning relative clause constructions. Some groups received cycles of unenhanced input with no tasks requiring production whereas other received cycles of enhanced input, in which the relative clause was highlighted. Other groups received either one of these two treatments, plus some tasks that required the production of relative clauses. Learners were subsequently tested on interpretation tasks, grammaticality judgments tasks, sentence com- 
bination tasks and sentence completion tasks. The results reveal that the input and output groups made greater gains compared with input-only groups. Izumi (2002: 566) concludes: In short, pushed output can induce the learners to process the input effectively for their greater interlanguage development.

Larsen-Freeman (1983) uses the metaphor of a car, which no matter how much fuel is available, will not move without ignition, release of brake and accelerator. This indispensible relation between input and output is a key concept in the research at hand. This study will investigate first, the effects of input enhancement and learners' output or pushed output ${ }^{1}$ on the learning of Type 3 Conditional sentences, and then a comparison of the two on the degree of the acquisition of the chosen linguistic form. Another area for investigation is the efficiency of processing instruction as an alternative technique. Therefore, this study will be a comparison of visually enhanced input, pushed output and processing instruction on the learning of the target linguistic form -Type 3 Conditionals-. A further aim of the study is to see if the knowledge gained by these three forms will retain well over time.

\section{Methodology}

The present study sets out to investigate the effects of three different attentiondrawing techniques used in grammar teaching with a focus on form. The aim is to discover the most effective technique for a second language grammar class. The chosen target form for the study is the past hypothetical Conditional (If Clause- Type 3). This form has also attracted the attention of other researches (Timm, 1986, Izumi et al., 1999). Since Conditional sentences include two clauses: a main clause and an if clause, the structure of the sentence is complex. Mastery of this structure requires a good grasp of the English tense system and the model auxiliaries.

The research questions posed for the study are based on the results of the prior empirical research. The five most important research questions in this study are as follows:

1. Does pushed output have any effect on the learning of Type 3 Conditional sentences?

2. Does visually enhanced input have any effect on the learning of Type 3 Conditional sentences?

3. Does processing instruction have any effect on the learning of Type 3 Conditional sentences?

4. Of the three types of attention drawing techniques, which is/are the most effective on the learning of Type 3 Conditional sentences?

5. Of the three attention gathering techniques, which best facilitates retaining the structure over time according to the results of the delayed post-test?

\subsection{Participants}

The participants of the study were chosen from the intermediate level (B Level) students of a public research university in Turkey. The participants were students enrolled at an

\footnotetext{
${ }^{1}$ The term pushed output is also used in the literature by Ellis, R. 1994 and Ellis, N. 2005.
} 
intensive English preparatory class of between 24 to 30 hours a week. The data collection was in the middle of the first semester. The level of the students was determined on the basis of a standard placement test (the Michigan Placement Test).

The selection of the participants was determined on the basis of a recognition test of the target form. Students who showed that they had some knowledge of the forms, determined as those with at least 48 correct answers (i.e. more than 50\%) in the pre-test were excluded. Because of the focus on intake, it was important that participants were unfamiliar with the target structure.

According to the results of this test, the total number decreased from 107 to 90 . Then these students were divided into four groups in order to form the experimental and control groups. The experimental and control groups were assigned randomly. The age of the subjects ranged from 17 to 21 .

Table 1. Number of Participants.

\begin{tabular}{lll}
\hline Pushed Output Group & 19 \\
Processing Instruction Group & & 23 \\
Visually Enhanced Input Group & & 25 \\
Control Group & Total & 23 \\
& & 90 \\
\hline
\end{tabular}

\subsection{Instruments}

The recognition test (pre-test) administered to all B level students, included 60 questions in different types; True/False, fill in the blanks, sentence completion and some production type of questions. In order not to make the target form salient, the test included different grammatical items, such as relative clauses, all types of Conditionals, and tenses. However, only the conditional questions, 25 of 60 questions, were graded. Each graded question was worth four, making a total of 100 .

The results of the pre-test were compared with the results of the post-test, which was administered after the treatment, in order to reveal whether a particular treatment had an effect on learning. The same test was also used as the delayed post-test administered four weeks later to test retention.

Researchers searching for the effects of input and output have used different post-tests, such as grammatically judgment tests, picture-cued production tests, sentence combination tests, and interpretation tests in different modes (Izumi et al, 1999; Izumi, 2002; Izumi, 2003; Erlam, 2003; Rosa \& O’Neill, 1999). In addition to these, we have included sentence completion, true/false, multiple choice, and yes/no questions on our test.

\subsection{Instructional Packs}

For the treatment, which lasted four hours for all groups, the researcher used New English File, Intermediate (Oxenden \& Latham, 2006) and English Grammar in Use (Murphy, 2004) regular coursebooks of the students-. However, in order to ensure the inclusion of the the salient characteristics of each type of attention drawing technique, for each experimental 
group and the control group an instructional pack of lesson plans and related activities was developed.

In order to reduce the possibility and giving one group an unfair advantage, uniformity of number of activities, time allowed, language level were important considerations in developing the packs. The same two texts (Monopoly and Truth about the Titanic) were used with all groups with activities appropriate to each group.

\subsection{Procedures}

107 intermediate level students were given the pre-test. The remaining students who were studying in four different classes were randomly assigned as the pushed output, visually enhanced input, processing instruction and the control group. The experimental groups were different from each other in respect to output requirements, exposure to the visually enhanced input, and practice that was input based for the processing instruction group.

Following the pre-test, all four groups were taught the target form by the researcher using the lesson plans developed for each group. All groups were taught by the researcher in order to eliminate the teacher function. The treatment took four hours for all groups. Immediately after, all the groups were given the post-test. The delayed post-test was given four weeks, the results of which were used to determine the most effective technique in terms of retention.

The traditional PPP (Presentation-Practice-Production) sequence was used in all experimental groups with some adaptations: for example; Enhanced Input Group was presented the linguistic item -Type 3 Conditional sentences- visually enhanced during the Presentation stage. However, the Pushed Output Group during the Production stage of PPP received text reconstruction activities that pushed them to produce output. The Processing Instruction Group, on the other hand, worked on activities that promoted their processing the input in the Practice stage.

\subsection{Data Analysis}

In order to answer research questions 1,2 and 3 focusing on the effectiveness of each attention-drawing technique, a one-way analysis of variance (ANOVA) was used. For the fourth research question it was decided to use multiple comparisons Post Hoc Tests which consist of pair wise comparisons to compare all different combinations of the treatment groups. These comparisons were done among groups according to the results gathered from the tests. The last research question concerned the retention of the target form. A comparison of the mean scores of the delayed post-tests for all groups provided the attention-gathering technique, which retained well over time. All the analyses were calculated with SPSS version 13.0 for Windows.

\section{Results}

The mean scores of the pre-test ranged from 38.7 to 40.2 with a total mean score of 39.6. Such close mean scores among all groups suggest a uniform level of students across 
the whole sample with a very similar level of knowledge of Type 3 conditional structures before the treatment. Hence, the statistical analysis indicated no statistically significant difference among the groups according to the results of the pre-test $\mathrm{p} d » .93$ which is higher than 0.05 ; therefore it is not significant $(\mathrm{F}=.148 ; \mathrm{df}=3 ; \mathrm{p}=.93)$.

Table 2. Results of Pre-test for All Groups.

\begin{tabular}{|c|c|c|}
\hline Groups & $\mathrm{N}$ & Mean \\
\hline Pushed Output Group & 19 & 40.2 \\
\hline Processing Instruction Group & 23 & 40 \\
\hline Visually Enhanced Input Group & 25 & 38.7 \\
\hline Control Group & 23 & 39.6 \\
\hline \multicolumn{2}{|c|}{ Total Mean } & 39.6 \\
\hline & Sig. & .93 \\
\hline
\end{tabular}

Table 3. T-Test for All Test Scores of Pushed Output Group.

\begin{tabular}{|c|c|c|c|c|c|c|}
\hline Groups & & & Mean & $\mathrm{t}$ & $\mathrm{df}$ & Sig. \\
\hline \multirow[t]{6}{*}{1} & Pair 1 & Results of Pre-test & 40.2 & -15.17 & 18 & .007 \\
\hline & & Results of Post-test & 81.4 & & & \\
\hline & Pair 2 & Results of Pre-test & 40.2 & -13.03 & 18 & .057 \\
\hline & & Results of Delayed Post-test & 75.1 & & & \\
\hline & Pair 3 & Results of Post-test & 81.4 & 2.46 & 18 & .001 \\
\hline & & Results of Delayed Post-test & 75.1 & & & \\
\hline
\end{tabular}

It can be clearly seen from the table above that the scores of the pushed output group increased significantly from the pre-test to the post-test $(\mathrm{t}=-15.17$; $\mathrm{df}=18$; pd» .007) leading to the conclusion that a structure is learnt effectively when attention is directed to the target item in the input via pushing the production of the target item.

Secondly, the comparison of the results of the post and delayed-post test scores reveals a decrease in test scores; however, we can still talk about a statistically significant difference between the scores. In essence it means that, the learners have gained scores from the delayed post-test which are very different from the post-test. This seems to reflect a loss of knowledge acquired after the treatment.

Table 4. T-Test for All Test Scores of Processing Instruction Group

\begin{tabular}{|c|c|c|c|c|c|c|}
\hline Groups & & & Mean & $\mathrm{t}$ & $\mathrm{df}$ & Sig. \\
\hline \multirow[t]{6}{*}{2} & Pair 1 & Results of Pre-test & 40 & -16.55 & 22 & .001 \\
\hline & & Results of Post-test & 77 & & & \\
\hline & Pair 2 & Results of Pre-test & 40 & -11.56 & 22 & .01 \\
\hline & & Results of Delayed Post-test & 79.4 & & & \\
\hline & Pair 3 & Results of Post-test & 77 & -.667 & 22 & .61 \\
\hline & & Results of Delayed Post-test & 79.4 & & & \\
\hline
\end{tabular}


The scores of the t-test for the pre-test and post-test of the processing instruction group reveal a statistical difference between the pre-test and the post-test. $(t=-16.55 ; \mathrm{df}=22 ; \mathrm{p}$ $\mathrm{d} \gg .001)$. This indicates that the scores gained from the post-test are considerably different from the scores gained from the pre-test. Since there exists an increase in the grades, it is possible to conclude that students learned equally effectively by this method, compared to the pushed output group.

Pair 3 gives us the $\mathrm{t}$-test results for the post-test and delayed post-test. This time $\mathrm{t}=$ $-.667 ; \mathrm{df}=22 ; \mathrm{p} d » .61$ which is not significant at $95 \%$ confidence level. This actually means that the scores gained after the post-test and delayed post-test are statistically not different from each other, a sign of evidence for retention. Because group members have not scored less in the delayed post-test, it seems they have not lost the gains to their interlanguage. Unlike Pushed Output group, Processing Instruction group indicate positive gains for the retention of the acquired target form.

Table 5. T-Test for All Test Scores of Visually Enhanced Input Group.

\begin{tabular}{lllllll}
\hline Groups & & & Mean & $\mathrm{t}$ & $\mathrm{df}$ & Sig. \\
\hline 3 & Pair 1 & Results of Pre-test & 38.7 & -9.36 & 24 & .10 \\
& Results of Post-test & 67.2 & & & \\
& Pair 2 & Results of Pre-test & 38.7 & -6.76 & 24 & .05 \\
& Results of Delayed Post-test & 61.2 & & & \\
& Pair 3 & Results of Post-test & 67.2 & 1.41 & 24 & .28 \\
& Results of Delayed Post-test & 61.2 & & & \\
\hline
\end{tabular}

In Table 5, we see the comparisons of the pre-test, post-test and delayed post-test for the visually enhanced input group. The t-test scores for each test pair reveal some interesting results. To start with, the t-test scores of Pair 1 (Pre-test-Post-test Results) do not reveal a statistically significant difference, $(\mathrm{t}=-9.36 ; \mathrm{df}=24 ; \mathrm{p} \mathrm{d}) .10$ which is not significant at $95 \%$ confidence level), reflecting no significant change from pre to post-test for this technique. In other words, visually enhanced input, as a method for gathering attention in focus on form has not been effective with this group.

Table 6. T-Test for All Test Scores of Control Group.

\begin{tabular}{|c|c|c|c|c|c|c|}
\hline Groups & & & Mean & $\mathrm{t}$ & $\mathrm{df}$ & Sig. \\
\hline \multirow[t]{3}{*}{4} & Pair 1 & $\begin{array}{l}\text { Results of Pre-test } \\
\text { Results of Post-test }\end{array}$ & $\begin{array}{l}39.6 \\
73.7\end{array}$ & -22.32 & 22 & .001 \\
\hline & Pair 2 & $\begin{array}{l}\text { Results of Pre-test } \\
\text { Results of Delayed Post-test }\end{array}$ & $\begin{array}{l}39.6 \\
72.3\end{array}$ & -14.94 & 22 & .007 \\
\hline & Pair 3 & $\begin{array}{l}\text { Results of Post-test } \\
\text { Results of Delayed Post-test }\end{array}$ & $\begin{array}{l}73.7 \\
72.3\end{array}$ & .72 & 22 & .001 \\
\hline
\end{tabular}

When the t-test results of the control group for each test was considered, it was seen that for this group, all test results are significant. It is highly significant for the pre-test and 
post-test (Pair $1 \mathrm{t}=-22.32 ; \mathrm{df}=22 ; \mathrm{p} \mathrm{d} » .001$ Pair $2 \mathrm{t}=-14.94 ; \mathrm{df}=22 ; \mathrm{p} \mathrm{d} » .007$ ) and post-test and delayed post-test (Pair $3 \mathrm{t}=.72 ; \mathrm{df}=22 ; \mathrm{p} \mathrm{d} » .001$ ) results. This significant result shows that in this group, forms learnt were still retained four weeks later.

After the processing instruction and pushed output groups, the control group was the next most successful in developing their interlanguage. In other words, the traditional type of teaching (Present-Practice-Produce with no extra emphasis on the input and output) benefited learners' interlanguage more than the visually enhanced input.

Table 7. Multiple Comparisons (Post Hoc Tests).

\begin{tabular}{lllll}
\hline $\begin{array}{l}\text { Dependent } \\
\text { Variable groups }\end{array}$ & $\begin{array}{l}(\mathrm{I}) \\
\text { groups }\end{array}$ & $\begin{array}{l}(\mathrm{J}) \\
(\mathrm{I}-\mathrm{J})\end{array}$ & Mean Difference & Sig. \\
\hline Results of & 1 & 2 & & .81 \\
Delayed & & 3 & -4.320 & .01 \\
Post-test & & 4 & $13.958\left(^{*}\right)$ & .93 \\
& 2 & 1 & 2.810 & .81 \\
& & 3 & 4.320 & .001 \\
& & 4 & $18.278\left(^{*}\right)$ & .41 \\
& 3 & 1 & 7.130 & .01 \\
& & 2 & $-13.958\left(^{*}\right)$ & .001 \\
& & 4 & $-18.278\left(^{*}\right)$ & .06 \\
& 4 & 1 & -2.810 & .41 \\
& & 2 & -7130 & .06 \\
\hline
\end{tabular}

1. Pushed Output Group 2.Processing Instruction Groupn 3.Visually Enhanced Input Group 4.Control Group

We conducted a post hoc test to answer the last research question, Among the three techniques, which facilitate(s) retention over time according to the results of the delayed post-test? The table above shows the multiple comparisons of groups in terms of retention. The results of delayed post-test were compared among the four groups and it was seen that processing instruction $(p<.001)$, pushed output $(p<.01)$ and the control groups were the three groups that had learnt best. It was noticeable that visually enhanced input was surprisingly the least successful.

\section{Discussion of FIndings}

According to the results of this study, three major findings are evident. First of all, the subjects engaged in the pushed output treatment outperformed exposed to the same input under different techniques in learning English Type 3 Conditionals. The statistically significant difference between the pre-test and post-test for the output group reveal this. Although it is not possible to talk about the statistically significant difference of pushed output technique with the delayed post-test, the immediate uptake is evident with the posttest results. Secondly, in contrast to the positive effect of pushed output, visually enhanced input failed to show any measurable effect on the noticing of the target input, which is clearly indicated by the scores. 
Finally, like pushed output, processing instruction reveals clear positive effects on the learning of the target form. Other than the positive effects on learning, it is statistically possible to say that processing instruction is the most useful technique for helping learners to retain new form in their interlanguage in the long term. Therefore, processing instruction does not only enhance noticing and learning, but also aids retention in the interlanguage of forms already processed.

The results reveal that students do not make use of typographical enhancement, that underlining or italicizing is not sufficient to draw learners' attention. The statistical analyses in this study show that students need opportunities to produce structures both in written and spoken output.

An explanation of this failure in terms of visually enhanced input's nonobservable effect on acquisition might be the issue of learner readiness or the students' developmental level of the target form. As Peinemann (1984) suggests, the effect of any given pedagogical treatment could be constrained by the student's developmental readiness. This may account for the minimal facilitative effect of this specific treatment on these learners. However, it should be noted that this fact is valid for the other treatment groups as well.

Other than producing the target form, creating opportunities for learners to process the input also helps. Students are more successful if given the opportunity to process new structures after presenting but before production. Processing instruction, the aim of which is to make learners get the communicative function of a structure, has significantly affected the retention of the chosen target form.

In regard to the to the fourth research question, the results indicate that pushed output seems to be the most effective attention-gathering technique, followed by processing instruction. Visually enhanced input and traditional teaching were the least effective techniques. This might be because during pushed output the teacher creates situations in which the learners are pushed to use the newly learnt target form. For the study, for example the learners were given extra oral and written opportunities to use the third Conditional sentences, both written and oral. Therefore, the positive effect of active participation in oral and written pair-work activities support the claim that there exists a link between interaction and grammatical development and highlight the importance of active participation in the interaction (Mackey, 1999). The pushed output group was exposed to the target form many times more than the visually enhaced input and control group.

The positive effect of pushed output demonstrated in this study is consistent with the hypothesized function of output in second language acquisition. In particular, based on the literature and research that point to the importance of drawing learners' attention to the form to promote their learning, pushed output was considered to be a means to achieve this. This study presents evidence that output enables this, by prompting learners to notice problems in their interlanguage through the production of language. Because the learners were given chance to produce the target form both orally and written, they were given the chance to increase awareness of problems with the target form in their IL. In short, pushed output as a means to gather the attention of the learners to form, can help the learners to process the input effectively for their greater IL development (Izumi, 2002).

Consistent with these results, Ellis and He (1999) also mention the positive effects of output production. In their experimental study of the differential effects of premodified input, 
interactionally modified input, and modified output of the comprehension of directions in a listen-and-do task and the acquisition of new words embedded in the directions, they report that the modified output group achieved higher comprehension and vocabulary acquisition scores than either of the input groups. Even though the scope of their study was on modifying the output and vocabulary, they still emphasize the role of output in SLA.

\subsection{Implications for Theory and Practice}

If pushed output and processing instruction are effective in learning of the target form and if processing instruction achieves good long-term retention, then teachers can use this in their classrooms. Instead of enhancing the input for the learner, creating environments for the students to produce output seems more beneficial. Even though only one type of linguistic item has been tested, in the light of the presented study, teachers may try a range of different target items in their classrooms.

Thus, teachers when planning their lesson-plans should be careful about the stages of Presentation-Practice-Production. This study has investigated the effectiveness of different techniques to be used at different stages of langauge teaching. As results indicate, visually enhanced input used as an attention drawing technique at the presentation stage has little effect on the learning of the linguistic form; however, a focus on attention drawing techniques at the practice and production stages will be beneficial for learners. To sum up, this study reveals that gathering the attention of the learner after presenting the input is more durable and more effective on the item to be learned.

\subsection{Conclusion}

This study aimed to find the most effective and durable attention gathering techniques used in focus on form, revealing results that are important both linguistically and pedagogically. The following conclusions can be drawn from the study:

1. Pushed output and processing instruction have positive and statistically significant effects on the acquisition of the Type 3 Conditional sentences for Turkish learners of English who have participated in the study.

2. Traditional teaching and visually enhanced input have no statistically significant effects on the learning of the Type 3 Conditional sentences for the same group of learners. However, it should be stated here that the traditional teaching group (the control group) did not receive all the activities of the other three experimental groups. Since these can also be considered as input, the extra activities used in the experimental groups gave them advantages.

3. Among four different techniques, processing instruction was the most durable for the learners when presented Type 3 Conditional sentences.

From the pedagogical aspect, this study suggests an alternative presentation to account for the learning of a chosen linguistic item. Thus, items should be presented in a way that ensures they are given as much of the leraners' attention as possible. Doughty (2003) notes that the issue of directing student attention to input has only recently begun to receive interest in SLA. In regard to this, this study discovered that pushing the learner to produce the target form as output during the production stage and practicing with processing instruction activities during the practice stage directs the learners' attention to form. 


\section{REFERENCES}

Brown, C. (1985). "Requests for specific language input: differences between older and younger adult learners", in S. M. Gass and C. G. Madden (eds.), Input in Second Language Acquisition. Cambridge: Newbury House Publishers.

Carr, T. H. \& Curran, T. (1994). "Cognitive factors in learning about structured sequences: applications to syntax", in Studies in Second Language Acquisition, 16: 205-30.

Cook, V. (2001). Second Language Learning and Language Teaching. New York: Hodder Arnold.

Doughty, C. (2001). "Cognitive underpinnings of focus on form", in P. Robinson (ed.), Cognition and Second Language Instruction. Cambridge: Cambridge University Press.

Doughty, C. J. (2003). "Instructed SLA: constraints, compensation, and enhancement", in C. J. Doughty and M. Long (eds.), The Handbook of Second Language Acquisition. Malden: Blackwell Publishing, 256-311.

Ellis, R. (1985). "Teacher pupil interaction in second language development", in S. M. Gass and C. G. Madden (eds.), Input in Second Language Acquisition. Cambridge: Newbury House Publishers.

Ellis, R. \& He, X. (1999). "The roles of modified input and output in the incidental acquisition of word meanings", in Studies in Second Language Acquisition, 21: 285-301.

Erlam, R. (2003). "Evaluating the relative effectiveness of structured-input and output-based instruction in foreign language learning", in Studies in Second Language Acquisition, 25: $559-582$.

Gass, S. M. \& Selinker, L. (2001). Second Language Acquisition: An Introductory Course. New Jersey: Lawrence Erlbaum.

Gass, S. M. (2003). "Input and interaction", in C. J. Doughty and M. H. Long (eds.), The Handbook of Second Language Acquisition. Malden: Blackwell Publishing, 224-55.

Gass, S. M. (2004). "Context and second language acquisition", In B. VanPatten, J. Williams, S. Rott, and M. Overstreet (eds.), Form-meaning Connections in Second Language Acquisition. New Jersey: Lawrence Erlbaum Associates.

Gass, S. M. \& Torres, M. J. A. (2005). "Attention when: an investigation of the ordering effect of input and interaction", in Studies in Second Language Acquisition, 27: 1-31.

Izumi, S., Bigelow, M., Fujiwara, M., and Fearnow, S. (1999). "Testing the output hypothesis: effects of output on noticing and second language acquisition", in Studies in Second Language Acquisition, 21: 421-52.

Izumi, S. (2002). "Output, input enhancement and the noticing hypothesis: an experimental study on ESL relativization", in Studies in Second Language Acquisition, 24: 541-77.

Izumi, S. (2003). "Comprehension and production processes in second language learning: in search of the psycholinguistic rationale of the output hypothesis", in Applied Linguistics, 24: $168-96$.

Larsen-Freeman, D. (1983). "Second language acquisition: getting the whole picture", in K. M. Long and S. Peck (eds.), Second Language Acquisition Studies. Rowley: Newbury House Publishers, Inc, 3-22.

Larsen-Freeman, D. \& Long, M. (1991). An Introduction to Second Language Acquisition Research. London: Longman.

Long, M. H. (1991). "Focus on form: a design feature in language teaching methodology", in K. de Bot, R. Ginsberg \& C. Kramsch, (eds.), Foreign Language Research in Cross-cultural Perspective. Amsterdam: Benjamins, 39-52. 
Mackey, A. (1999). "Input, interaction and second language development: an empirical study of question formation in ESL", in Studies in Second Language Acquisition, 21: 557-587.

Murphy, R. (2004). English Grammar in Use. Cambridge: Cambridge University Press.

Oxenden, C. \& Latham, C. 2006: New English File. Portugal: Oxford University Press.

Pica, T. \& Doughty, C. (1985). "Input and interaction in the communicative language classroom: a comparison of teacher-fronted and group activities", in S. M. Gass and C. G. Madden, (eds.), Input in Second Language Acquisition. Cambridge: Newbury House Publishers.

Pienemann, M. (1984). "Psychological constraints on the teachability of languages", in Studies in Second Language Acquisition, 6: 186-214.

Rosa, E. \& O'Neill, M. D. (1999). "Explicitness, intake and the issue of awareness: another piece to the puzzle", in Studies in Second Language Acquisition, 21:511-56.

Schmidt, R. (1990). "The role of consciousness in second language learning", in Applied Linguistics, 11: 206-26.

Schmidt, R. (1995). "Consciousness and foreign language learning: a tutorial on the role of attention and awareness in learning", in R. Schmidt (ed.), Attention and Awareness in Foreign Language Learning. Honolulu, Hawai'i: University of Hawai'i Second Language Teaching and Curriculum Center.

Schmidt, R. (2001). "Attention", in P. Robinson (edt.), Cognition and Second Language Instruction. Cambridge: Cambridge University Press.

Shehadeh, A. (2002). "Comprehensible output, from occurrence to acquisition: an agenda for acquisitional research", in Language Learning, 52: 597-647.

Smith, M. S. (1993). "Consciousness raising and the second language learner", in Applied Linguistics, 2: 36-48.

Swain, M. (1985). "Communicative competence: some roles of comprehensible input and comprehensible output in its development”, in S. Gass and C. Madden (eds.), Input in Second Language Acquisition. Rowley, MA: Newbury House.

Swain, M. (1993). "The output hypothesis: just speaking and writing are not enough", in The Canadian Modern Language Review, 50: 158-164.

Swain, M. (1995). "Three functions of output in second language learning", in G. Cook and B. Seildhofer (eds.), Principles and Practice in the Study of Language. Oxford: Oxford University Press, 125-144.

Swain, M. (1998). "Focus on form through conscious reflection", in C. Doughty and J. Williams (eds.), Focus on Form in Classroom Second Language Acquisition. New York: Cambridge University Press, 64-81.

Swain, M. (2000). "French immersion research in Canada: recent contributions to SLA and applied linguistics", in Annual Review of Applied Linguistics, 20: 199-212.

Timm, J. P. (1986). "The consistency of interlanguage in task-bound second language production", in Applied Linguistics, 7: 86-107.

VanPatten, B. (1994). "Evaluating the role of consciousness in second language acquisition: terms, linguistic features and research methodology", in International Association of Applied Linguistics (AILA) Review, 11: 27-36.

VanPatten, B. (2002). "Processing instruction: an update", in Language Learning, 52: 755-803.

VanPatten, B. (2003). Processing Instruction: Theory, Research, and Commentary. New Jersey: Lawrence Erlbaum Associates. 